\title{
THE EFFECT OF HEMOGLOBIN ON RENAL FUNCTION IN THE HUMAN
}

\author{
By JOHN H. MILLER AND ROGER K. MCDONALD ${ }^{1}$ \\ (From the National Heart Institute, National Institutes of Health, Bethesda, Md.; and the \\ Gerontology Section, Baltimore City Hospitals, Baltimore, Md.)
}

(Submitted for publication May 16, 1951; accepted July 9, 1951)

It has long been noted that the occurrence of hemoglobinuria is frequently associated with oliguria, anuria, and renal failure. The cause of this impairment of renal function which accompanies the excretion of hemoglobin has been variously ascribed to obstruction of tubular lumina by precipitated hemoglobin or hemoglobin derivatives ( 1 , $2)$, to renal ischemia associated with hemoglobinemia (3), or to a toxic action of hemoglobin on the kidney (4). More recently it has been postulated that the renal damage associated with the excretion of hemoglobin or heme containing substances is not due primarily to hemoglobin, but is caused by renal ischemia on the basis of shock ( 5 , $6)$, which is frequently present in conditions under which hemoglobinuria occurs, e.g., intravascular hemolysis following mismatched transfusion, the crush syndrome, and blackwater fever. This latter viewpoint holds that the presence of heme pigments in the plasma and urine is merely an incidental finding (6). It has been supported by a number of reports on the intravenous administration of hemoglobin solutions to the human (7-12) which generally agree that hemoglobin can be administered without untoward reaction, although no data on acute renal functional studies have been reported. Recently, however, Amberson and associates (13) have reported late and persistent decreases in renal clearances in a single hypertensive subject following the injection of hemoglobin.

Thus, not only has the mechanism of renal failure which frequently accompanies hemoglobinuria not been conclusively demonstrated, but the presence or absence of a deleterious effect of hemoglobin on the human kidney has not been clearly established.

During the course of a study of the glomerular permeability to hemoglobin, it soon became apparent that the administration of hemoglobin solu-

1 Present address: U. S. Public Health Service Hospital, Wyman Park Drive, Baltimore 11, Maryland. tions to the human was attended by noteworthy alterations in renal function. The present report is concerned with observations on changes in renal function induced by the presence of extracorpuscular hemoglobin.

\section{METHODS}

Twenty-five male subjects who ranged in age from 24 to 65 years were selected for the present study from the wards of the Baltimore City Hospitals and the Baltimore City Infirmary. All subjects were adjudged to be free of cardiovascular and renal disease on the basis of the following criteria: (1) diastolic blood pressure below $90 \mathrm{~mm}$. $\mathrm{Hg}$, (2) absence of evidence of valvular heart disease or of cardiac enlargement, (3) absence of proteinuria in morning specimen by the heat-acetic acid test, (4) absence of abnormal findings on microscopic examination of sediment of freshly voided urine, (5) plasma nonprotein nitrogen below $35 \mathrm{mg}$. per cent, and (6) glomerular filtration rate and effective renal plasma flow within two standard deviations of the mean value for the subject's age group (14).

All subjects were studied in the fasting state. Approximately one liter of water was given by mouth during the two-hour period preceding the test; thereafter, $200 \mathrm{cc}$. of water were given at half-hour intervals during the procedure. The oral administration of sodium bicarbonate in a dosage of $2 \mathrm{gm}$. every four hours was instituted at approximately 18 hours before the test and was continued throughout the procedure.

The renal clearances of inulin and of p-aminohippurate $(\mathrm{PAH})$ were determined before and after the intravascular administration of hemoglobin according to the methods of Goldring and Chasis (15).

In all experiments blood was sampled at the midpoint of each urine collection period through an indwelling needle in the femoral artery. Urine was obtained through a multi-eyed urethral catheter, and each urine collection period was terminated by washing the bladder with 100 cc. of physiological saline. Complete evacuation was assured by subsequent injection of air. Blood pressure, which was determined sphygmomanometrically, and pulse rate were measured twice during each urine collection period.

Inulin was determined in plasma and urine by the method of Harrison (16). PAH was determined in cadmium sulfate filtrates of plasma and in diluted urine by the method of Bratton and Marshall (17). 
TABLE I

Renal functional changes following the intravascular administration of autogenous hemolyzed blood.* Mean values for a group of 20 subjects

\begin{tabular}{|c|c|c|c|c|c|}
\hline & Control† & Period 4 & Period 5 & Period 6 & Period 7 \\
\hline $\begin{array}{l}\text { Inulin clearance }(c c . / \text { min. }) \\
\text { PAH clearance }(c c . / \text { min. }) \\
\text { Filtration fraction } \\
\text { Urine flow }(c c . / \text { min.) } \\
\text { Unresorbed filtrate (per cent) }\end{array}$ & $\begin{array}{l}107 \\
576 \\
\quad .189 \\
5.8 \\
5.2\end{array}$ & $\begin{array}{r}85 \\
285 \\
.310 \\
2.4 \\
2.9\end{array}$ & $\begin{array}{c}81 \\
299 \\
\quad .275 \\
3.0 \\
3.6\end{array}$ & $\begin{array}{c}81 \\
307 \\
\quad .270 \\
3.3 \\
3.9\end{array}$ & $\begin{array}{c}79 \\
321 \\
\quad .248 \\
3.1 \\
3.8\end{array}$ \\
\hline
\end{tabular}

* 12-15 gm. of hemoglobin administered over a period of 15 minutes. Periods $4-7$ represent consecutive 20-minute urine collection periods after the appearance of hemoglobinuria.

$\dagger$ Mean of three 12-minute urine collection periods. Values not corrected for body surface area.

Plasma hemoglobin determinations were carried out according to the method of Evelyn and Malloy (18). The subjects were divided into three groups according to experimental design.

Group I. $(N=20)$. Following three 12-minute control urine collection periods, autogenous blood, freshly hemolyzed in distilled water was injected intravascularly. This hemoglobin solution was prepared by drawing $15 \mathrm{cc}$. of blood from the subject into a syringe containing $35 \mathrm{cc}$. of distilled water with a few drops of heparin. During the 36 minute control period, a total of 90 to $105 \mathrm{cc}$. of blood was withdrawn in this fashion, yielding 300 to 350 cc. of hemoglobin solution. This quantity of solution which contained an estimated 12-15. gm. of hemoglobin, assuming that complete or nearly complete hemolysis occurred, was then injected over a period of approximately 15 minutes. A few minutes after the appearance of hemoglobinuria, urine was collected in four consecutive periods, each of 20 minutes duration. In four of the subjects in this group, a radiopaque intravenous catheter was passed from an antecubital vein into the right renal vein under fluoroscopic control, and the fraction of $\mathrm{PAH}$ extracted from the plasma by the kidney was determined by simultaneous sampling of peripheral arterial and renal venous blood during control periods and following the injection of hemoglobin.

Group II. $(N=10)$. Following three control urine collection periods, 12 to $14 \mathrm{gm}$. of hemoglobin in the form of a 7.1 per cent commercially prepared solution ${ }^{2}$ was injected intravascularly over a period of eight to ten minutes. Subsequent to the appearance of hemoglobinuria, urine was obtained in five consecutive 20-minute collection periods.

Group III. $(N=6)$. Following three 12-minute control urine collection periods, an intravenous infusion of either a 6.05 or 7.1 per cent hemoglobin solution (Sharp and Dohme) was instituted at the rate of approximately $1 \mathrm{cc}$. or 60 to $70 \mathrm{mg} . / \mathrm{min}$. Urine was obtained serially in collection periods of 15 minutes duration over a period of two to three hours, during which time the infusion of

2 The hemoglobin solution employed in the present study was kindly supplied by Sharp and Dohme, Inc., Glenolden, $\mathrm{Pa}$. The preparation is a stable solution of reduced human hemoglobin, free of red cell stroma and of electrolyte content approximating that of plasma (19). hemoglobin was maintained, and subsequently for an additional period of 60 to 90 minutes after discontinuance of the infusion.

Following 18 of the 36 experiments, determinations of the clearances of inulin and $\mathrm{PAH}$ were repeated at 24 or 48 hours after the injection of hemoglobin.

\section{RESULTS}

The injection of either the autogenous hemolyzed blood preparation or the commercially prepared hemoglobin solution was productive of the following physiological changes, all of which were statistically significant ${ }^{3}:(1)$ an increase in the systolic and diastolic blood pressures, (2) a decrease in the pulse rate, (3) a decrease in the clearance of inulin and in the clearance of $\mathrm{PAH}$, (4) an increase in the filtration fraction, (5) a decrease in the urine flow, and (6) an increase in the per cent of glomerular filtrate reabsorbed by the renal tubules.

Group I. Following the injection of autogenous hemolyzed blood, the mean systolic blood pressure increased from $126 \mathrm{~mm}$. Hg during the control periods to 143 during the first postinjection period; the mean diastolic pressure increased from 78 to 93; the mean pulse pressure increased from 48 to 50 ; while the mean pulse rate decreased from 67 during control periods to 56 during the first postinjection period. Blood pressure remained significantly elevated and pulse rate remained significantly decreased during the entire 80 -minute postinjection observation period.

The changes in renal clearances and in urine flow are shown in Table I. The mean depression of $\mathrm{C}_{\mathrm{PAH}}$ during the first postinjection period was

3 The term "significant" in the present report is used to indicate statistical significance at the 1 per cent level of confidence as determined by the t-test of Fisher. 
50.1 per cent, while the mean depression of $\mathrm{C}_{\text {IN }}$ was 20.8 per cent. The clearances of both $\mathrm{PAH}$ and inulin remained significantly depressed during the entire 80-minute postinjection period. The filtration fraction was increased from a control value of 0.189 to 0.310 during the first postinjection period and remained significantly elevated throughout the 80 -minute postinjection period.

The control urine flow of $5.8 \mathrm{cc}$. $/ \mathrm{min}$. decreased to $2.4 \mathrm{cc}$./min. during the first postinjection period and remained significantly depressed throughout the 80-minute observation period. The per cent of filtrate unresorbed by the tubules likewise decreased from a control value of 5.2 per cent to 2.9 per cent during the first postinjection period. The percentage reabsorption of filtrate during the last period (i.e., 60-80 minutes after the injection of hemoglobin) did not differ significantly, however, from the control value.

It can be seen in Table II that the renal extraction of PAH following the injection of hemoglobin was essentially unchanged in three of four subjects. This observation indicates that the clearance of $\mathrm{PAH}$ remained a valid measure of renal plasma flow, and that the observed depression in $\mathrm{PAH}$ clearance was due to an actual decrease in renal plasma flow rather than to an impairment of tubular function. In subject J. B., the renal extraction of $\mathrm{PAH}$ of 0.934 during the control periods decreased to 0.732 and to 0.681 following the injection of hemoglobin. This depression may have been due either to impairment of tubular function or to displacement of the tip of the catheter to the orifice of the renal vein. Regardless of the cause of the depression, it should be noted that the per cent decrements in $\mathrm{C}_{\mathrm{PAH}}$ and in true renal plasma flow remain in fairly close agreement.

Group II. Following the rapid injection of the commercially prepared hemoglobin solution at a rate of approximately $1.5 \mathrm{gm}$./min., systolic blood pressure increased from a mean control value of $107 \mathrm{~mm}$. $\mathrm{Hg}$ to 140 during the first postinjection period; diastolic pressure increased from 76 to 98 ; pulse pressure increased from 31 to 42 ; and the mean pulse rate decreased from 64 during control periods to 56 during the first postinjection period. As was the case in the group receiving an injection of hemolyzed blood, there was subsequently no significant change in blood pressure or pulse rate during the 100 -minute postinjection period.

$\mathrm{C}_{\mathrm{PAH}}$ was depressed 62 per cent for the group during the first postinjection period and, although plasma flow was still significantly depressed from control levels during the last period (i.e., 80 to 100 minutes), it had shown a significant increase from the fourth period in a return toward baseline levels. Glomerular filtration rate was decreased 37 per cent during the first postinjection period and, as was the case with $\mathrm{C}_{\mathrm{PAH}}$, although it was still significantly depressed at 100 minutes, it had shown a significant increase toward baseline levels: The filtration fraction, which was elevated throughout the experimental period, showed a significant

TABLE II

Renal extraction of $P A H$ following hemoglobin*

\begin{tabular}{|c|c|c|c|c|c|c|c|c|}
\hline Subject & Function & Control & \multicolumn{2}{|c|}{ Period 4} & \multicolumn{2}{|c|}{ Period 5} & \multicolumn{2}{|c|}{ Period 6} \\
\hline E. H. & $\begin{array}{l}\text { PAH Ext. } \\
\text { CPAB }_{\text {PA. }}(c c . / m i n .) \\
\text { RPF }(c c . / \text { min. })\end{array}$ & $\begin{array}{l}475^{.905} \\
525\end{array}$ & $231^{.911}$ & $\begin{array}{l}\begin{array}{c}\text { per cent } \\
\text { change }\end{array} \\
\\
-51.4 \\
-51.7\end{array}$ & $292^{.909}$ & $\begin{array}{l}\text { per cent } \\
\text { change } \\
\\
-38.6 \\
-38.9\end{array}$ & $\begin{array}{l}314^{.918} \\
342\end{array}$ & $\begin{array}{l}\text { per cent } \\
\text { change } \\
\\
-33.9 \\
-34.9\end{array}$ \\
\hline J.F. & $\begin{array}{l}\text { PAH Ext. } \\
\text { CPAH }(c c . / \min .) \\
\text { RPF }(c c . / \min .)\end{array}$ & $\begin{array}{l}772^{.968} \\
798\end{array}$ & $\begin{array}{l}229^{.953} \\
240\end{array}$ & $\begin{array}{l}-70.4 \\
-70.0\end{array}$ & & & & \\
\hline J. A. & $\begin{array}{l}\text { PAH Ext. } \\
\text { CPAH }_{\text {PPF }(c c . / m i n .)} \\
\text { RP. } / \text { min. })\end{array}$ & $\begin{array}{l}458^{.939} \\
488\end{array}$ & $6^{64} .918$ & $\begin{array}{l}-86.0 \\
-85.7\end{array}$ & $106^{.874}$ & $\begin{array}{l}-76.9 \\
-75.3\end{array}$ & & \\
\hline J. B. & $\begin{array}{l}\text { PAH Ext. } \\
\text { CPAH }(c c . / m i n .)_{\text {RPF }(c c . / m i n .)}\end{array}$ & $\begin{array}{l}590^{.934} \\
632\end{array}$ & $126^{.732}$ & $\begin{array}{l}-78.7 \\
-72.8\end{array}$ & $226^{.681}$ & $\begin{array}{l}-61.7 \\
-47.5\end{array}$ & & \\
\hline
\end{tabular}

* 12-15 gm. of hemoglobin administered over a period of 15 minutes. 


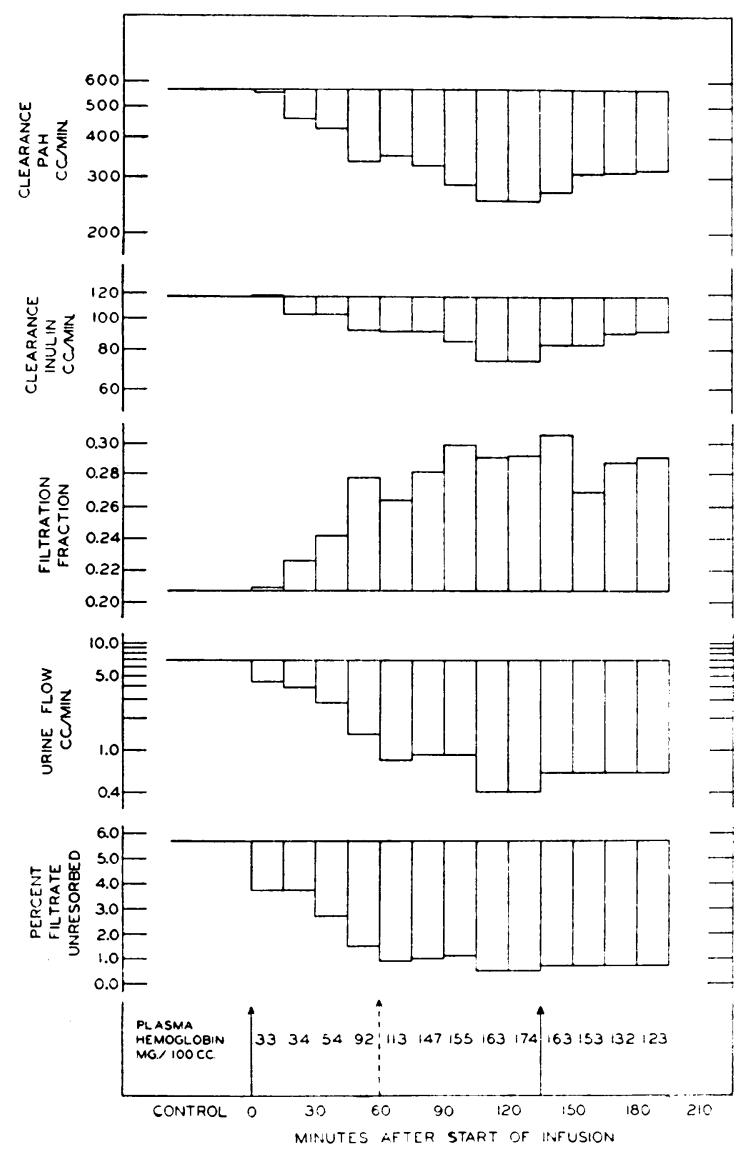

Fig. 1. Renal Functional Changes During the Intravenous Infusion of a Commercially Prepared Hemoglobin Solution at a Rate of 70 Mg./min.

Control values represent the mean of three urine collection periods each of 12 minutes duration. Solid arrows represent the beginning and end of the hemoglobin infusion. Broken arrow represents the point at which hemoglobinuria occurred.

decline from period 4 to period 8 toward control levels (Table III).

The mean control urine flow of $6.1 \mathrm{cc}$. $/ \mathrm{min}$. decreased to $1.9 \mathrm{cc} . / \mathrm{min}$. during the first period following the injection of hemoglobin. Although urine flow was still significantly decreased (3.9 $\mathrm{cc} . / \mathrm{min}$.) during period 8 , it increased progressively toward baseline levels throughout the 100 minute observation period. The mean per cent of filtrate unresorbed by the tubules decreased from a control value of 5.2 per cent to 2.5 per cent during the first postinjection period, and as was the case with hemolyzed blood, tubular reabsorption of filtrate during period 8 was no longer significantly elevated from control levels (Table III).
Group III. The administration of hemoglobin solution at a rate of approximately 60 to $70 \mathrm{mg}$./ min. was productive of a progressive decrease in renal plasma flow and glomerular filtration rate, a progressive increase in blood pressure and filtration fraction. and a progressive decrease in urine flow. A typical infusion experiment is represented in Figure 1. It should be noted that changes in urine flow and in renal hemodynamics occurred during the first urine collection period, when as little as a few hundred milligrams of hemoglobin had been infused. Following cessation of the infusion, there was a gradual return of plasma flow, filtration rate, urine flow, and blood pressure toward baseline values.

In follow-up clearance studies performed in 18 of the 36 experiments at 24 to 48 hours after the injection of hemoglobin, the clearances of inulin and $\mathrm{PAH}$ did not differ significantly from the prehemoglobin control clearance values.

\section{DISCUSSION}

It has been suggested that the untoward effects which may accompany the injection of hemoglobin preparations in the human or in the experimental animal may be due not to hemoglobin per se, but to the presence of other factors such as red cell stroma, potassium released from the red cell, organic solvents employed as laking agents, bacterial contamination of the solution, or toxic derivatives of hemoglobin, such as, methemoglobin $(11,12$, 20). Although the agent effective in producing the alterations in renal function observed in the present study has not been clearly identified, it seems most likely that either hemoglobin per se or some product of its intravascular catabolism was responsible.

Qualitatively, the same renal functional changes occurred with both the hemolyzed blood preparation and the commercially processed solution. Neither bacterial contamination nor organic laking agents were present in either of these solutions; nor could the presence of methemoglobin be demonstrated spectrophotometrically in either preparation. Although red cell stroma, and potassium in excess of normal plasma concentration were present in the hemolyzed blood preparation, these factors were both absent in the commercially prepared hemoglobin solution. 
TABLE III

Renal functional changes following the intravascular administration of a commercially prepared hemoglobin solution*

\begin{tabular}{|c|c|c|c|c|c|c|c|}
\hline Subject & Function & Controlt & Period 4 & Period 5 & Period 6 & Period 7 & Period 8 \\
\hline R. K. & $\begin{array}{l}\text { Inulin clearance }(c c . / \text { min.) } \\
\text { PAH clearance }(c c . / \text { min.) } \\
\text { Filtration fraction } \\
\text { Urine flow (cc./min.) } \\
\text { Unresorbed filtrate (per cent) }\end{array}$ & $\begin{array}{l}80 \\
399 \\
.205 \\
1.4 \\
1.7\end{array}$ & $\begin{array}{l}32 \\
81 \\
.395 \\
0.5 \\
1.6\end{array}$ & $\begin{array}{l}44 \\
123 \\
.358 \\
0.8 \\
1.8\end{array}$ & $\begin{array}{l}47 \\
159 \\
.296 \\
1.0 \\
2.1\end{array}$ & $\begin{array}{l}501 \\
201 \\
.249 \\
1.5 \\
3.0\end{array}$ & $\begin{array}{l}194 \\
194 \\
.227 \\
1.5 \\
3.4\end{array}$ \\
\hline R. H. & $\begin{array}{l}\text { Inulin clearance } \\
\text { PAH clearance } \\
\text { Filtration fraction } \\
\text { Urine flow } \\
\text { Unresorbed filtrate }\end{array}$ & $\begin{array}{l}117 \\
673 \\
11.5 \\
9.8 \\
9.8\end{array}$ & $\begin{array}{l}60 \\
221 \\
.271 \\
1.5 \\
2.5\end{array}$ & $\begin{array}{l}52 \\
222 \\
.243 \\
1.7 \\
3.1\end{array}$ & $\begin{array}{l}255 \\
.216 \\
2.0 \\
3.6\end{array}$ & $\begin{array}{l}75 \\
329 \\
.228 \\
3.6 \\
4.8\end{array}$ & $\begin{array}{l}72 \\
338 \\
.213 \\
4.6 \\
6.4\end{array}$ \\
\hline W. P. & $\begin{array}{l}\text { Inulin clearance } \\
\text { PAH clearance } \\
\text { Filtration fraction } \\
\text { Urine flow } \\
\text { Unresorbed filtrate }\end{array}$ & $\begin{array}{l}133 \\
727 \\
.183 \\
3.1 \\
2.3\end{array}$ & $\begin{array}{c}83 \\
280 \\
.296 \\
1.4 \\
1.7\end{array}$ & $\begin{array}{l}96 \\
367 \\
.262 \\
2.3 \\
2.4\end{array}$ & $\begin{array}{l}84 \\
323 \\
.260 \\
1.6 \\
1.9\end{array}$ & $\begin{array}{c}99 \\
386 \\
.256 \\
1.8 \\
1.8\end{array}$ & $\begin{array}{l}87 \\
351 \\
.248 \\
1.5 \\
1.7\end{array}$ \\
\hline J. W. & $\begin{array}{l}\text { Inulin clearance } \\
\text { PAH clearance } \\
\text { Filtration fraction } \\
\text { Urine flow } \\
\text { Unresorbed filtrate }\end{array}$ & $\begin{array}{l}118 \\
669 \\
.176 \\
1.6 \\
1.4\end{array}$ & $\begin{array}{c}72 \\
304 \\
.237 \\
1.1 \\
1.5\end{array}$ & $\begin{array}{l}72 \\
299 \\
.241 \\
2.9 \\
4.0\end{array}$ & $\begin{array}{l}72 \\
299 \\
.241 \\
2.9 \\
4.0\end{array}$ & $\begin{array}{l}73 \\
304 \\
.240 \\
1.8 \\
2.5\end{array}$ & $\begin{array}{l}74 \\
344 \\
.215 \\
2.2 \\
3.0\end{array}$ \\
\hline W. L. & $\begin{array}{l}\text { Inulin clearance } \\
\text { PAH clearance } \\
\text { Filtration fraction } \\
\text { Urine flow } \\
\text { Unresorbed filtrate }\end{array}$ & $\begin{array}{c}160 \\
1008 \\
.159 \\
4.8 \\
3.0\end{array}$ & $\begin{array}{l}72 \\
293 \\
.246 \\
1.2 \\
1.7\end{array}$ & $\begin{array}{c}78 \\
366 \\
.213 \\
2.1 \\
2.7\end{array}$ & $\begin{array}{l}74 \\
429 \\
.172 \\
2.5 \\
3.4\end{array}$ & $\begin{array}{l}89 \\
511 \\
.174 \\
3.4 \\
3.8\end{array}$ & $\begin{array}{l}98 \\
534 \\
.184 \\
4.2 \\
4.3\end{array}$ \\
\hline F. B. & $\begin{array}{l}\text { Inulin clearance } \\
\text { PAH clearance } \\
\text { Filtration fraction } \\
\text { Urine flow } \\
\text { Unresorbed filtrate }\end{array}$ & $\begin{array}{l}99 \\
664 \\
.150 \\
9.0 \\
9.1\end{array}$ & $\begin{array}{l}60 \\
201 \\
.298 \\
1.2 \\
2.0\end{array}$ & $\begin{array}{l}75 \\
298 \\
.252 \\
2.4 \\
3.2\end{array}$ & $\begin{array}{l}80 \\
352 \\
\quad .227 \\
3.4 \\
4.2\end{array}$ & $\begin{array}{l}78 \\
395 \\
.197 \\
4.0 \\
5.1\end{array}$ & $\begin{array}{l}76 \\
386 \\
.197 \\
4.6 \\
6.0\end{array}$ \\
\hline E. H. & $\begin{array}{l}\text { Inulin clearance } \\
\text { PAH clearance } \\
\text { Filtration fraction } \\
\text { Urine flow } \\
\text { Unresorbed filtrate }\end{array}$ & $\begin{array}{l}87 \\
560 \\
.156 \\
4.5 \\
5.2\end{array}$ & $\begin{array}{l}72 \\
278 \\
.259 \\
2.8 \\
3.9\end{array}$ & $\begin{array}{l}69 \\
253 \\
.273 \\
2.8 \\
4.0\end{array}$ & $\begin{array}{l}256 \\
252 \\
.262 \\
2.6 \\
3.9\end{array}$ & $\begin{array}{l}64 \\
250 \\
.256 \\
2.8 \\
4.4\end{array}$ & $\begin{array}{l}69 \\
278 \\
.248 \\
3.0 \\
4.3\end{array}$ \\
\hline H. H. & $\begin{array}{l}\text { Inulin clearance } \\
\text { PAH clearance } \\
\text { Filtration fraction } \\
\text { Urine flow } \\
\text { Unresorbed filtrate }\end{array}$ & $\begin{array}{l}140 \\
711 \\
.196 \\
9.9 \\
7.1\end{array}$ & $\begin{array}{l}104 \\
324 \\
.321 \\
3.5 \\
3.4\end{array}$ & $\begin{array}{l}100 \\
373 \\
.268 \\
4.2 \\
4.2\end{array}$ & $\begin{array}{c}96 \\
377 \\
.255 \\
5.0 \\
5.2\end{array}$ & $\begin{array}{l}109 \\
436 \\
.250 \\
7.0 \\
6.4\end{array}$ & $\begin{array}{l}113 \\
433 \\
.261 \\
7.2 \\
6.4\end{array}$ \\
\hline P. N. & $\begin{array}{l}\text { Inulin clearance } \\
\text { PAH clearance } \\
\text { Filtration fraction } \\
\text { Urine flow } \\
\text { Unresorbed filtrate }\end{array}$ & $\begin{array}{l}117 \\
655 \\
.179 \\
5.4 \\
4.8\end{array}$ & $\begin{array}{l}72 \\
289 \\
.249 \\
2.8 \\
3.9\end{array}$ & $\begin{array}{l}68 \\
271 \\
\\
.251 \\
2.4 \\
3.5\end{array}$ & $\begin{array}{l}73 \\
304 \\
.240 \\
2.8 \\
3.8\end{array}$ & $\begin{array}{l}82 \\
345 \\
.238 \\
4.3 \\
5.2\end{array}$ & $\begin{array}{c}91 \\
361 \\
.252 \\
4.7 \\
5.2\end{array}$ \\
\hline W. T. & $\begin{array}{l}\text { Inulin clearance } \\
\text { PAH clearance } \\
\text { Filtration fraction } \\
\text { Urine flow } \\
\text { Unresorbed filtrate }\end{array}$ & $\begin{array}{l}137 \\
829 \\
10.166 \\
7.6\end{array}$ & $\begin{array}{l}125 \\
366 \\
\\
.342 \\
3.1 \\
2.5\end{array}$ & $\begin{array}{l}114 \\
367 \\
.311 \\
3.8 \\
3.3\end{array}$ & $\begin{array}{l}140 \\
454 \\
.308 \\
2.6 \\
1.8\end{array}$ & $\begin{array}{l}124 \\
451 \\
.275 \\
2.9 \\
2.3\end{array}$ & $\begin{array}{l}129 \\
423 \\
.305 \\
5.9 \\
4.6\end{array}$ \\
\hline Mean & $\begin{array}{l}\text { Inulin clearance } \\
\text { PAH clearance } \\
\text { Filtration fraction } \\
\text { Urine flow } \\
\text { Unresorbed filtrate }\end{array}$ & $\begin{array}{l}119 \\
690 \\
.174 \\
6.1 \\
5.2\end{array}$ & $\begin{array}{c}75 \\
264 \\
.291 \\
1.9 \\
2.5\end{array}$ & $\begin{array}{l}77 \\
294 \\
.267 \\
2.5 \\
3.2\end{array}$ & $\begin{array}{l}79 \\
320 \\
.248 \\
2.6 \\
3.4\end{array}$ & $\begin{array}{c}84 \\
361 \\
.236 \\
3.3 \\
3.9\end{array}$ & 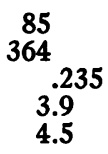 \\
\hline
\end{tabular}

* 12-14 gm. of hemoglobin administered over a period of 8-10 minutes. Periods 4-8 represent consecutive 20minute urine collection periods after the appearance of hemoglobinuria.

$\dagger$ Mean of three 12-minute urine collection periods. Values not corrected for body surface area. 
Comparing the responses to the single injection of hemolyzed blood (Group I) and to the single injection of commercial hemoglobin solution (Group II), it will be noted that the fall in PAH clearance, expressed as either the absolute or per cent decrement, was significantly greater after commercial hemoglobin. Blood pressure increased in all subjects, somewhat more in Group II than in Group I. A reduction in renal vascular caliber, which was greater for the stroma-free preparation than for the hemolyzed blood, therefore, must have occurred. Although the total amount of hemoglobin administered was approximately the same for both solutions, the hemoglobin of the more concentrated commercial preparation was injected at approximately twice the rate of the hemoglobin of the hemolyzed blood preparation. The quantitative difference in the effect of the two preparations may well be explained on a time-dosage basis. In accord with this explanation is the fact that when the commercial preparation was infused slowly (Group III), the vasoconstrictive response was less marked.

The demonstration of a renal vasoconstrictive phenomenon in the human following the intravascular injection of hemoglobin is in accord with the findings of other observers who have measured renal blood flow in the dog by plethysmographic methods. Reid demonstrated that the intravenous injection of either distilled water or of autogenous blood laked with distilled water or ether was productive of an immediate decrease in renal volume $(21,22)$. Mason and Mann (23) likewise demonstrated a decrease in the renal volume in the dog following the injection of a hemoglobin solution, but noted no change in renal volume after the administration of a saline suspension of red cell stroma. Similar findings of renal vasoconstriction induced by hemoglobin were reported by Hesse and Filatov (3). A pressor effect in the human was noted by Amberson and associates (13), who reported an increase in blood pressure and a slowing of pulse rate following the injection of hemoglobin.

For many years the oliguria and renal failure which occur with hemoglobinuria were generally attributed to obstruction of the renal tubules by casts and debris of hemoglobin or its derivatives $(1,2,24,25)$, since such material was commonly found to be present in the tubules at autopsy. More recently, the significance of intraluminal deposition of hemoglobin substances in the production of anuria and renal failure has been questioned $(5,6)$. It has been pointed out that there is little correlation between the degree of tubular obstruction observed at autopsy and the degree of suppression of urine flow observed clinically, and that not infrequently, the degree of blockage observed at postmortem is insufficient to account for anuria (5).

Although the significance of the role of tubular obstruction by hemoglobin and its derivatives in the production of renal failure cannot be evaluated from the present study, the data suggest that renal damage associated with hemoglobinuria may be due primarily to renal ischemia on the basis of renal vasoconstriction induced by the presence of extracorpuscular hemoglobin. The intravascular administration of hemoglobin in dosages as low as $0.5 \mathrm{gm}$. in the human has been shown to result promptly in renal vasoconstriction. Although the dosages employed in the present study produced only a transient renal hemodynamic response, insofar as renal clearances had returned to baseline levels by 24 or 48 hours after the injection of hemoglobin, it is not inconceivable that a more intense or more prolonged hemoglobinemia might produce renal ischemia of sufficient intensity and duration to result in either reversible or irreversible renal damage.

Moreover, it must be remembered that shock is not infrequently present in conditions which result in the occurrence of hemoglobinuria or myoglobinuria. Renal vasoconstriction and decreased renal plasma flow have been described in both experimental (26) and clinical (27) shock. In such circumstances, the summation of the effects of shock and hemoglobinemia on the kidney may result in renal ischemia of intensity and duration sufficient to effect renal damage.

The clinical association of oliguria with the phenomenon of hemoglobinuria finds an interesting parallel in the present study. The presence of hemoglobin, free in the plasma, produced a prompt decrease in urine flow. The infusion studies demonstrated the occurrence of this phenomenon in the absence of hemoglobinuria at plasma levels well below the renal threshold for hemoglobin. 
Two factors contribute to the oliguria following the injection of hemoglobin: a decrease in the rate of glomerular filtration and an increase in the per cent of filtrate reabsorbed by the renal tubules. Although the cause of this increased tubular reabsorption is not understood, it would not appear to be on the basis of unselective reabsorption of filtrate by damaged tubules as postulated by Van Slyke (28) as being responsible for the oliguria and anuria following shock, inasmuch as the maintainence of tubular integrity has been demonstrated in the present studies by an unchanged renal extraction of PAH following the administration of hemoglobin.

During the past decade considerable interest has been aroused in the possibility of utilizing hemoglobin solutions as a plasma or blood substitute $(9,12,29,30)$. It has been pointed out that such solutions would not only exert colloid osmotic pressure in the restoration of blood volume but would also possess the ability to transport oxygen. The demonstration in the present study of moderate to intense renal vasoconstriction produced by hemoglobin in amounts far less than would be used in the treatment of shock, seriously questions the feasibility of employing hemoglobin solutions for therapeutic purposes.

\section{SUMMARY AND CONCLUSIONS}

A total of 36 renal clearance studies was performed on 25 male subjects before and after the intravascular administration of hemoglobin in dosages ranging up to $15 \mathrm{gm}$.

The injection of either an autogenous hemolyzed blood preparation or a commercially prepared hemoglobin solution promptly resulted in the following physiological changes: (1) an increase in the systolic and diastolic blood pressures, (2) a decrease in the pulse rate, (3) a decrease in the clearances of inulin and PAH, (4) an increase in the filtration fraction, (5) a decrease in the urine flow, and (6) an increase in the per cent of glomerular filtrate reabsorbed by the renal tubules. The renal extraction of PAH at low plasma levels was essentially unchanged following the administration of hemoglobin.

In follow-up studies performed in 18 of the 36 experiments at 24 to 48 hours after the injection of hemoglobin, inulin and PAH clearances had returned to control levels.

It is suggested that renal vasoconstriction induced by the presence of extracorpuscular hemoglobin may play an important role in the production of renal damage associated with hemoglobinuric states.

\section{ACKNOWLEDGMENTS}

The authors express their appreciation to Mrs. Eleanore Roach, Mrs. Elsie Beard, Miss Margaret McCollum, and Mr. Charles Punte for technical assistance.

\section{REFERENCES}

1. Baker, S. L., and Dodds, E. C., Obstruction of the renal tubules during the excretion of hemoglobin. Brit. J. Exper. Path., 1925, 6, 247.

2. DeGowin, E. L., Osterhagen, H. F., and Andersch, M., Renal insufficiency from blood transfusion. I. Relation to urinary acidity. Arch. Int. Med., 1937, 59, 432.

3. Hesse, E., and Filatov, A., Experimentelle Untersuchungen über das Wesen des Hämolytischen Shocks bei der Bluttransfusion und die therapeutische Beeinflussung desselben. I. Die Nierenfunktionsstörungen im akuten Experiment. Ztschr. f. d. ges. exper. Med., 1933, 86, 211.

4. Bordley, J., Reactions following transfusion of blood, with urinary suppression and uremia. Arch. Int. Med., 1931, 47, 288.

5. Maegraith, B., Blackwater fever anuria. Tr. Roy. Soc. Trop. Med. \& Hyg., 1944, 38, 1.

6. Maegraith, B. G., Havard, R. E., and Parsons, D. S., Renal syndrome of wide distribution induced possibly by renal anoxia. Lancet, 1945, 2, 293.

7. Sellards, A. W., and Minot, G. R., Injection of hemoglobin in man and its relation to blood destruction, with especial reference to the anemias. J. Med. Research, 1916, 34, 469.

8. Ottenberg, R., and Fox, C. L., Jr., The rate of removal of hemoglobin from the circulation and its renal threshold in human beings. Am. J. Physiol., 1938, $123,516$.

9. O'Shaughnessy, L., Mansell, H. E., and Slome, D., Hemoglobin solution as a blood substitute. Lancet, 1939, 2, 1068.

10. Fairley, N. H., The fate of extracorpuscular circulating hemoglobin. Brit. Med. J., 1940, 2, 213.

11. Gilligan, D. R., Altschule, M. D., and Katersky, E. M., Studies of hemoglobinemia and hemoglobinuria produced in man by intravenous injection of hemoglobin solutions. J. Clin. Invest., 1941, 20, 177.

12. Phillips, R. A., Kidney. Ann. Rev. Physiol., 1949, 11, 493.

13. Amberson, W. R., Jennings, J. J., and Rhode, C. M., Clinical experience with hemoglobin-saline solutions. J. Appl. Physiol., 1949, 1, 469. 
14. Davies, D. F., and Shock, N. W., Age changes in glomerular filtration rate, effective renal plasma flow, and tubular excretory capacity in adult males. J. Clin. Invest., 1950 29, 496.

15. Goldring, W., and Chasis, H., Hypertension and $\mathrm{Hy}-$ pertensive Disease. The Commonwealth Fund, New York, 1944.

16. Harrison, $H$. E., A modification of the diphenylamine method for the determination of inulin. Proc. Soc. Exper. Biol. \& Med., 1942, 49, 111.

17. Bratton, A. C., and Marshall, E. K., Jr., A new coupling component for sulfanilamide determination. J. Biol. Chem., 1939, 128, 537.

18. Evelyn, K. A., and Malloy, H. T., Microdetermination of oxyhemoglobin, methemoglobin and sulfhemoglobin in a single sample of blood. J. Biol. Chem., 1938, 126, 655.

19. Pennell, R. B., and Smith, W. E., Preparation of stabilized solutions of hemoglobin. Blood, 1949, 4, 380.

20. Hamilton, P. B., Farr, L. E., Hiller, A., and Van Slyke, D. D., Preparation of hemoglobin solutions for intravenous infusion. J. Exper. Med., 1947, 86, 455.

21. Reid, W. L., Changes in the volume of the kidney in the intact animal; a plethysmographic study with especial reference to diuretics. Am. J. Physiol., 1929, 90, 157.

22. Reid, W. L., The effect of intravenous injections of distilled water on the kidney. Am. J. Physiol., 1929, 90, 168.
23. Mason, J. B., and Mann, F. C., The effect of hemoglobin on the volume of the kidney. Am. J. Physiol., 1931, 98, 181.

24. Ponfick, E., Experimentelle Beiträge zur Lehre von der Transfusion. Arch. f. path. Anat., 1875, 62, 273.

25. Barratt, J. O. W., and Yorke, W., An investigation into the mechanism of production of blackwater. Ann. Trop. Med., 1909, 3, 1.

26. Phillips, R. A., Dole, V. P., Hamilton, P. B., Emerson, K., Jr., Archibald, R. M., and Van Slyke, D. D., Effects of acute hemorrhagic and traumatic shock on renal function of dogs. Am. J. Physiol., 1946, $145,314$.

27. Lauson, H. D., Bradley, S. E., and Cournand, A., Renal circulation in shock. J. Clin. Invest., 1944, 23, 381.

28. Van Slyke, D. D., The effects of shock on the kidney. Ann. Int. Med., 1948, 28, 701.

29. Amberson, W. R., Jacobs, J. E., Hisey, A., and Monke, J. V., Hemoglobin-saline solutions as transfusion media, in Blood Substitutes and Blood Transfusion, edited by Mudd, S., and Thalhimer, W. Charles C Thomas, Springfield, Ill., 1942, Chap. 19, p. 156.

30. Cannon, R. K., and Redish, J., The large scale production of crystalline human hemoglobin: with preliminary observations on the effect of its injection in man, in Blood Substitutes and Blood Transfusion, edited by Mudd, S., and Thalhimer, W. Charles C Thomas, Springfield, IIl., 1942, Chap. 18, p. 147. 